\title{
CONGRESS AND LITERACY TESTS: A COMMENT ON CONSTITUTIONAL POWER AND LEGISLATIVE ABNEGATION
}

\author{
Douglas B. Maggs* and Lawrence G. Wallace $\dagger$
}

On September 9, I96I, the United States Commission on Civil Rights submitted to Congress and to the President its 196r Report on Voting. The report contains a detailed exposition of information gathered by the Commission in its investigations and study during the preceding two years, culminating in conclusional findings that "there are reasonable grounds to believe that substantial numbers of Negro citizens are, or recently have been, denied the right to vote on grounds of race or color in about roo counties in 8 Southern States"; that "a common technique of discriminating against would-be voters on racial grounds involves the discriminatory application of legal qualifications for voters," including "requirements that the voter be able to read and write, that he be able to give a satisfactory interpretation of the Constitution, [and] that he be able to calculate his age to the day"; and that in addition there are denials of "the right to vote ... in some places . . . by the arbitrary or discriminatory application of various registration procedures, such as . . . the rejection of applicants for registration, or the removal of voters from the rolls, on grounds of minor technical errors in the completion of required forms; . . applying any or all of [specified registration requirements] . . to some would-be voters but not to others, or applying them differently to different persons; . . . providing assistance to some would-be voters but declining to provide it for others."1

Based in part on these findings, and on the Commission's attendant recommendations, ${ }^{2}$ several bills embodying corrective measures were introduced in the United States Senate and referred for study to that body's Subcommittee on Constitutional Rights of the Committee on the Judiciary. The principal bill was S. $2750^{3}$ sponsored

- A.B. 1922, J.D. I924, University of California; S.J.D. 1926, Harvard University. Late Professor of Law, Duke University. Because of his sudden, untimely death on September 14, 1962, Professor Maggs did not have an opportunity to approve all of the final version of this article.

: + A.B. 1952, M.P.A. 1954, Syracuse University; LL.B. 1959, Columbia University. Assistant Professor of Law, Duke University.

The research assistance of Michael R. Walsh, a third-year student at Duke University School of Law, is gratefully acknowledged.

${ }^{1}$ U.S. Commission on Civil. Rights, Report on Voting 135, 137-38 (1961). Findings of the Commission not directly related to the legislative proposals to be discussed are omitted from this quotation.

It is unnecessary to reiterate here any of the numerous deplorable examples, specified in the Report, of discriminatory application of voting criteria. Similar examples have been reported in a number of prior studies. See, e.g., U.S. Commission on Civil Rights, Report 90-95 (1959); Marganet Price, Tuiz Negro and the Ballot in the South (r959); Equality Before the Law, A Symposium on Civil Rights, 54 Nw. U.L. REv. 330, 368-71 (1959); Note, Use of Literacy Tests to Restrict the Right to Vote, 31 Notre DAMe LAw. 25I, 258-60 (and references there cited) (1959).

${ }^{2}$ U.S. Commission on Crvil Rights, Report on Voting $139-42$ (196I).

87th Cong., 2d Sess. (I962). The administration bill was also introduced in the House of Representatives as H.R. 10034, 87th Cong., 2d Sess. (1962). 
by the Kennedy administration and introduced jointly by the majority and minority leaders of the Senate. The chief innovation of S. $275^{\circ}$ was its provision that no person otherwise qualified shall be denied the right to vote in any federal election ${ }^{4}$ "on account of his performance in any examination, whether for literacy or otherwise," if he "has completed the sixth primary grade of any public school or accredited private school in any State or territory, the District of Columbia, or the Commonwealth of Puerto Rico." An earlier bill ${ }^{6}$ provided for a similar sixth-grade criterion (omitting territorial and Puerto Rican schools, however) for exemption from literacy and related tests in both state and federal elections; while a third bill, ${ }^{7}$ which most closely followed the Commission's rg6r recommendations, not only provided for the sixth-grade exemption from literacy and related tests in all elections (with no apparent limitation on the place-or language-of the schooling) but also provided that only four specified qualifications ${ }^{8}$ (in addition to literacy) could be applied (uniformly to all persons throughout the state) to bar citizens of the United States from voting in state or federal elections. All three bills contained recitals of congressional findings of racially discriminatory application of voting qualifications, in addition to their operative provisions.?

\section{An Episode in the "Worid's Greatest Deliberative Body"}

The course of senatorial consideration of these bills during the spring of 1962 was quite remarkable. In early February, within a few days after S. $275^{\circ}$ was referred to the Subcommittee on Constitutional Rights, the chairman of that subcommittee, Senator Ervin of North Carolina, sent letters to the attorneys general of the fifty states and to professors of constitutional law at some I5o law schools throughout the country, soliciting their views as to the "constitutionality and desirability" of the proposed legislation. ${ }^{10}$ These letters from Senator Ervin contained, in addition to brief summaries of the bills' provisions, references to several provisions of the Constitution

-The bill defines "federal election" as "any general, special, or primary election held solely or in part for the purpose of electing or selecting any candidate for the office of President, Vice President, presidential elector, Member of the Senate, or Member of the House of Representatives, Delegate, or Commissioner from the territories or possessions." The term will be so used in this article, and elections not included within this definition will be referred to as "state elections."

${ }^{5}$ According to testimony by Attorney General Kennedy, this provision would forbid use of the prospective voter's accuracy in filling in his application form as a qualifying test. Hearings Before the Subcommittee on Constitutional Rights of the Senate Committee on the ludiciary on S. 480, S. 2750, and S. 2979, 87th Cong., 2 d Sess. 297-98 (I962) [hereinafter cited as Fearings].

'S. 480,87 th Cong., Ist Sess. (196I). ${ }^{7}$ S. 2979,87 th Cong., 2 d Sess. (I962).

8 The four are reasonable age requirements, reasonable residence requirements, disqualification for legal confinement at the time of election or registration, and disqualification for conviction of a felony.

'For full texts of the three bills, see Hearings 7-9. Detailed analysis of the bills will be omitted from this discussion, now that the likelihood of enactment of any of them seems extremely remote. For analysis of two of the bills by one of the present writers, see id, at 589-97 (letter from Douglas B. Maggs). See also id. at 9-54 (analytical memoranda by Legislative Reference Service of the Library of Congress). For comment on some problems in the draftsmanship of the bills, see id. at 567-68, 632-33 (letters from A. Pratt Kesler and Arthur E. Sutherland).

${ }^{20}$ Id. at $14,523-24,573-74$. 
and decisions of the Supreme Court (requesting an opinion as to whether the bills were reconcilable therewith), but no reference to the reports of the Civil Rights Commission or to any other source of factual information that might have bearing on the desirability (and constitutionalityl) of the legislation. As one might anticipate, the replies, reprinted in the record of the hearings, ${ }^{11}$ are devoted almost exclusively to the question of constitutionality and only occasionally is there a passing reference to the possible need for or desirability of the proposed legislation. The hearings themselves were conducted before the subcommittee during seven days in late March and early April. Their focus was set in the chairman's opening statement, which was in essence a detailed legal brief arguing, on the basis of historical materials and Supreme Court precedents, that the proposed legislation would be unconstitutional. Witnesses appearing before the subcommittee were then repeatedly asked by the chairman and by the chief counsel (both of whom, incidentally, were undeviating in the courtesy and propriety with which they conducted their offices) to comment upon these alleged constitutional infirmities. Thus, while a 688-page record of hearings emerged from the subcommittee, it is a record prolix in debate and expressions of opinion on a few questions of constitutional law and meager in exposition of factual information that might be thought to call for congressional action.

This record of the hearings served, moreover, as the only committee communication to the Senate on the subject of the literacy test bills. The Senate leadership, having despaired of getting a literacy bill reported out of the Judiciary Committee (chaired by Senator Eastland of Mississippi), decided to by-pass committee after the conclusion of the hearings by raising S. 2750 on the floor as an amendment to a minor pending bill. There followed an extended floor debate, ${ }^{12}$ beginning in earnest on April 25 and lasting through May ro. Again the opponents concentrated their fire on alleged constitutional infirmities, with occasional digressions to argue that the proposed legislation might do more harm than good and that existing federal law, if vigorously enforced, would be wholly adequate to meet the situation. It is almost amusing to read some of these appeals for more vigorous enforcement from men who strongly opposed enactment of the Civil Rights Acts of 1957 and 1960, inviting speculation about the sort of welcome a battery of Justice Department lawyers sent into the South for this purpose would receive from these very Senators; but the serious point is that the subcommittee had received authoritative testimony ${ }^{18}$ that

${ }^{11} I d$. at 524-664. These include, a reply by one of the present writers, which arrives at the same substantive conclusions as this article. Id. at 589-97 (letter from Douglas B. Maggs).

${ }^{12}$ While the debate was sometimes referred to in the press and elsewhere as a "filibuster," the term can be applied only loosely since the daily sessions were not prolonged for extra hours and all participants in the debate confined their remarks (within normal senatorial standards) to the general subject of the bills.

${ }^{13}$ Hearings 264 (testimony of Attorney General Kennedy). See also xo8 Conc. Rec. 7244-45 (daily ed. May 7, r962) (letter from Acting Deputy Attorney General Katzenbach explaining in detail the lengthy procedural history of a particular suit brought under the Civil Rights Acts of 1957 and $\times 960$ ). 
the present laws, with their piecemeal approach and problems of proof, ${ }^{14}$ do not afford a practical means of expeditiously stamping out the widespread discriminatory disfranchisement that is being perpetrated under the guise of administering literacy tests. The bill's proponents tended to divide their efforts on the floor between attempts to defend against the elaborate constitutional attack and rather generalized pronouncements about voting rights. No one succeeded in wresting the initiative from the opposition sufficiently to infuse the chamber with a sense of urgency about the need for the legislation. Overall, the hearings and debates tended to convey the impression of a morass of constitutional problems and insufficient reason for Congress to try to do anything in the face of them.

The decisive votes in the Senate came on motions to close the debate. Under the current rules, an affirmative vote by two-thirds of the Senators present and voting is required for cloture. On Wednesday, May 9, 1962,43 Senators voted for, and 53 voted against cloture; although immediately after that vote a motion to table the literacy bill was defeated by a vote of 33 in favor to 64 opposed. $^{15}$ Twenty-one Senators who had voted against cloture, plus one who had announced his opposition to cloture but had withheld his vote because of pairing, changed sides and voted against tabling the bill. If these 22 Senators had voted in favor of cloture, the motion would have passed by the necessary two-thirds vote $\left(6_{5}\right.$ to 32$)$. Yet, when the cloture vote was repeated on Monday, May I4, not a single Senator voted differently than he had the first time and the result was almost identical: 42 in favor and $5^{2}$ opposed. ${ }^{16}$ The next day, by a vote of 49 to 34 , the Senate agreed to proceed to the consideration of other business, ${ }^{17}$ thus effectively killing the literacy test bill for the session. Although a few non-Southern Senators who voted against cloture were heard on the floor to profess support for the traditions of untrammeled senatorial debate, ${ }^{18}$ it seems clear that doubts about the constitutionality (and perhaps also about the efficacy) of the legislation were an at least equally potent factor accounting for the large number of Senators who would not let the debate end even though they found it good politics to go on record in opposition to the motion to

14 The inadequacies of existing remedies are convincingly canvassed in Heyman, Federal Remedies for Voteless Negroes, 48 Carif. L. Rev. 190 (1960). Professor Heyman's discussion of problems of proof and of obtaining a jury verdict in criminal cases, $i d$. at $200-01$, is particularly relevant because of Senator Ervin's repeated complaint, e.g., Hearings $287-88$, that the Department of Justice is not using the criminal remedies available to it. The difference between existing and proposed remedies was well summed up in the testimony of Dean Griswold as "the difference between retail and wholesale." Id. at I56.

${ }^{15}$ 108 Cong. REc. 7444 (daily ed. May 9, r962).

10 I08 Cong. Rec. 7659 (daily ed. May I4, 1962).

17 ro8 Cong. REc. 7768-69 (daily ed. May 15, I962).

${ }^{18}$ Perhaps the most extreme position was expressed by Senator Cotton of New Hampshire, who spoke of the anti-cloture tradition as preserving "the only spot in government where small minorities cannot be smothered by huge majorities" and thus as meriting special support from "a Senator from a small State, who may some day find the welfare of his own people threatened by combinations representing the more powerful and populous States of this Nation ...." I08 Cong. Rec. 744I (daily ed. May 9, 1962). But see note 20 infra. Such views, needless to say, can significantly modify in practice the concept of equal senatorial representation of each state worked out in the Constitutional Convention's great compromise (and query whether this is a modification that will always work to the advantage of the small states whose voices are amplified in the Senate to begin with). 
table. We are supported in this conclusion by the fact that only three months later, on August $\mathrm{r}_{4}$, the Senate, by a vote of 63 to 27 , dramatically invoked cloture (for the first time in thirty-five years) in order to bring the administration's communications satellite bill to a favorable vote. ${ }^{19}$ Among those voting in favor of cloture on that occasion were $I_{5}$ of the 22 straddle-voters on the literacy bill (and one of the 22 had died in the interim) plus 9 other Senators who had voted against cloture in the literacy votes. ${ }^{20}$ Another indication of the serious inroads made by the opponents' constitutional arguments is the fact that at least three Senators who can be counted as quite regular supporters of voting rights legislation stated on the floor of the Senate that they were convinced of the bill's unconstitutionality. ${ }^{21}$

The strategy of the bill's opponents thus must be rated a definite success, and a success that seems all the more notable when the insubstantiality of their basic constitutional argument is considered. Our purpose in the remainder of this article is primarily to show why we think that, if enacted, an anti-literary test statute comparable to S. 2750 would and should be upheld as constitutional by the United States Supreme Court. We put the matter this way in an effort to avoid confounding the issue of Congress's constitutional power with non-constitutional policy questions of federalism and congressional judgment. ${ }^{22}$ We shall also comment on some aspects of the proponents' unsuccessful tactics and finally offer a few suggestions as to how the Senate might have considered the literacy test problem more meaningfully if it had not been impeded by a smoke screen of chimerical constitutional fears. We hasten to add that the constitutionality of the proposed legislation has recently been discussed in three thoughtful student law review pieces, two published after the bill was finally shunted aside ${ }^{23}$ and one prepared in advance of the hearings

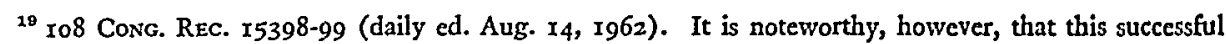
cloture vote was made possible only because 7 Southern-oriented Democratic Senators managed to be absent. Since these 7 had announced that if present and voting each would vote nay, there was even in this instance more than one-third of the total Senate membership announced as opposed to the cloture.

${ }^{20}$ One of these 9, curiously, was Senator Cotton of New Hampshirc, whose remarks of three months earlier are summarized in note 18 supra. Perhaps a modicum of consistency can be found for Senator Cotton in the fact that the opposition to the communications satellite bill was of a non-regional nature.

${ }^{21}$ I08 Cong. Rec. 7659 (daily ed. May 14, 1962) (Senator Kefauver of Tennessee); 108 Cono. Rec. 7559 (daily ed. May ro, I962) (Senator Bartlett of Alaska); ro8 Cong. Rec. 7343-44, 7441-42 (daily ed. May 8 and 9, I962) (Senator Cooper of Kentucky). Senator Cooper offered a substitute bill that he thought would cure constitutional defects. See 108 CoNG. REc. 7662, 7715-18 (daily ed. May 14, 1962). Almost three months later, Senator Dodd of Connecticut said on the Senate floor that his "discussions with many Members of this body" led him to conclude that "doubts about the constitutional issues... . accounted in large part for the outcome" of the cloture votes. I08 Cong. REc. 13925 (daily, ed. July 27, 1962).

${ }^{23}$ Not only did these questions tend occasionally to be blurred together during the hearings and debates, but the matter was further complicated by arguments that the Senate must exercise an independent judgment on the question of constitutionality irrespective of what the Supreme Court would hold. Sce, in particular, Hearings $33 \mathrm{I}$ (remarks by Attorney General Gallion of Alabama predicting the Supreme Court would uphold the proposed legislation as constitutional but arguing it would be unconstitutional nonetheless). Such arguments, when they are directed solely to legislative self-restraint and admit that the legislation would be upheld on the merits upon judicial review, seem to us to be indistinguishable for practical purposes from policy arguments directed to Congress's discretionary judgment.

${ }^{23}$ Comment, Congressional Authority to Restrict the Use of Literacy Tests, 50 CalIF. L. REv, 265 (1962); Note, The Constitutionality of Federal Anti-Literacy Test Legislation, 46 MinN. L. REv. 1076 (I962). 
on the basis of the Civil Rights Commission's legislative recommendations. ${ }^{24}$ All three agree that at least some form of anti-literacy test legislation using the sixthgrade criterion would be constitutional, and each contributes helpful research and analysis to which we shall occasionally refer. In our judgment, however, the discussion still can be advanced by an article directly meeting the main thrust of the opposition arguments; and so we have not been deterred from our endeavor.

\section{II}

\section{Constitutionality}

The relative complexity of the question of constitutionality is partly attributable to the rather large number of possibly relevant constitutional provisions and their interrelationship in the opposition argument. The basic provisions concerning the selection of Representatives, Senators, and Presidential Electors are contained separately in article I, section 2; the seventeenth amendment; and article II, section $\mathrm{I}$, respectively. Article I, section 4 adds that "the Times, Places and Manner of holding Elections for Senators and Representatives, shall be prescribed in each State by the Legislature thereof; but the Congress may at any time by Law make or alter such Regulations, except as to the Places of chusing Senators." The thirteenth, fourteenth, and fifteenth amendments each contain a section specifying that Congress shall have power, "by appropriate legislation," to enforce their provisions, including the mandate of the fifteenth amendment that "the right of citizens of the United States to vote shall not be denied or abridged by the United States or by any State on account of race, color, or previous condition of servitude." There is also a provision in article IV, section 4 that "the United States shall guarantee to every State in this Union a Republican Form of Government ...."25 Finally, and not to be forgotten, there is the famous "sweeping clause" of article I, section 8, specifying that "Con-

21 Werdegar, The Constitutionality of Federal Legislation to Abolish Literacy Tests: Civil Rights Commission's 1961 Report on Voting, 30 GEo. WASH. L. REv. 723 (1962), also printed in Hearings $601-13$.

${ }^{36}$ Although challenges to congressional action on the ground of inconsistency with this "guaranty clause" are considered non-justiciable, Georgia v. Stanton, 73 U.S. (6 Wall.) 50 (I867); Baker v. Carr, 369 U.S. 186,224 (1962) (dictum), the Supreme Court has not considered itself barred from ruling that an act of Congress is unconstitutional merely because one of the grounds asserted in support of the act is congressional power under the guaranty clause, Coyle v. Smith, 221 U.S. 559, 567-68 (I9II). Thus, anti-literacy test legislation grounded on this constitutional provision would be subject to judicial review, but there is very little in decided cases to indicate what the Court would hold to be the extent of congressional power under the guaranty clause. Restrictive implications can be found in the decision in Minor v. Happersett, 88 U.S. (2I Wall.) 162 (I874), where the Court rejected a claim that the guaranty clause (in the absence of any federal legislation) entitled women to state suffrage. Rather surprisingly, considering the earlier holding that such guaranty clause claims are non-justiciable in Luther v. Borden, 48 U.S. (7 How.) I (I849), the Court discussed the merits of the constitutional claim in Minor, 88 U.S. (2I Wall.) at $175-76$, and rejected it on the ground that it was "too late to contend that a government is not republican, within the meaning of this guaranty in the Constitution" merely because it denies suffrage to a class of citizens that was denied suffrage by all or nearly all of the original states when the Constitution was adopted.

Since no one is proposing federal anti-literacy test legislation applicable only to state elections, and all proposed bills would apply either exclusively to federal elections or to both federal and state elections, the possibility of congressional power under the guaranty clause will not be discussed further, except in so far as it may bear on interpretation of Congress's article I powers. See text at notes $33-36$ infra. 
gress shall have Power ... To make all Laws which shall be necessary and proper for carrying into Execution the foregoing Powers, and all other Powers vested by this Constitution in the Government of the United States, or in any Department or Officer thereof."

The opponents' argument, in brief outline, begins with the proposition that the Constitution plainly provides that voting qualifications for congressional elcctions are to be prescribed by the states. This is based on the language of article $\mathrm{r}$, section 2, repeated almost verbatim in the seventeenth amendment, that "the Electors in each State shall have the Qualifications requisite for Electors of the most numerous Branch of the State Legislature."26 The word "Manner" in article I, section 4 thus is not to be interpreted as referring to qualifications for voting in contravention of the more explicit provisions on the subject; and the same principle, it is argued, precludes any theory of implied congressional power to alter voting qualifications. All this is said to be made even more evident by the fact that whenever Congress has wished to proscribe the use of particular qualifications for voting, it has done so by means of constitutional amendments (specifically, the fifteenth, nineteenth, and proposed "anti-poll tax" amendments) rather than by legislation. No such amendment has been adopted to forbid the use of literacy tests; indeed, the Supreme Court has squarely held that literacy test requirements are constitutionally permissible ${ }^{27}$ and they are currently in use in twenty-one states. ${ }^{28}$ The argument concludes that because literacy tests are within the constitutional prerogative of the states to prescribe, federal sanctions against their use, in order to be "appropriate legislation" authorized by the fourteenth or fifteenth amendment, must reach only instances of administration of the tests to accomplish the kinds of discrimination prohibited by those amendments, and cannot be any form of blanket proscription of the literacy tests themselves.

This incomplete summary is sufficient to show the two-fold structure of the opposition argument as it relates to congressional power under the fourteenth and fifteenth amendments. The argument depends, first, on the proposition that under the remainder of the Constitution without considering those two amendments all power over literacy qualifications is reserved to the states and beyond the reach of Congress, and, secondly, on a restrictive interpretation of the congressional power to enforce those two amendments. While we believe the latter contention to be

${ }^{20}$ The argument is even stronger with respect to presidential electors, whom article II, section I says "each State shall appoint, in such manner as the Legislature thereof may direct . . . " See text at notes 52-54 infra.

${ }^{27}$ Lassiter v. Northampton Election Bd., 360 U.S. 45 (1959); Guinn v. United States, 238 U.S. 347, 366 (I915); Williams v. Mississippi, 170 U.S. 213, 221 (1898). But see note 80 infra.

28 The requirements in nineteen of these states, as they existed in 1959 , are described in Lassiter $v$. Northampton Election Bd., 360 U.S. 45, 52 n.7 (1959). Alaska and Hawaii are the other two states that impose such tests. For a complete survey of laws governing voting qualifications in all fifty states, see Hearings Before the Subcommittee on Constitutional Amendments of the Senate Committce on the Judiciary on Nomination and Election of President and Vice President and Qualifications for Voting, 87th Cong., rst Sess. 993-1060 (1962). 
the more clearly erroneous, we shall first discuss the other constitutional aspects, not only because they involve an essential underpinning of the entire opposition argument, but also because they are regarded by proponents as an alternative source of constitutional support for the proposed legislation, if limited to federal elections, and thus must be appraised as a factor in deciding upon the advisability of so limiting the legislation.

\section{A. Article I and Implied Powers}

While there has been no definitive judicial interpretation of the election provisions in article $I$ and the seventeenth amendment, the traditional view seems to support the opponents' contention that voting qualifications were left exclusively to state determination. ${ }^{29}$ It seems to have been generally assumed that congressional power under article $I$, section 4 to alter the "manner" of holding elections extends, as one opposition Senator succinctly put it, to the "how" but not to the "who."30 Direct and unequivocal support for this position is to be found in Hamilton's writings in The Federalist Papers, ${ }^{31}$ and a passage by Madison in those papers seems to give additional support. $^{32}$

The most far-reaching argument to the contrary has been made by Professor Crosskey. While admitting that his is not the generally accepted view, ${ }^{33}$ he contends that article I, section 2 merely ties together voting qualifications for congressional elections with those for elections of the most numerous branch of the state legislature without specifying who shall prescribe such qualifications; that article $I$, section 4 (interpreting "manner" in accordance with its usage in such contexts at the time) confers this power initially upon the states but notes that it is subject to congressional alteration; and indeed that such congressional power actually derives from the general powers of Congress limited in this respect only by article IV's guaranty to the states of a republican form of government. ${ }^{34}$ With all due respect for the plausibility of his supporting arguments based on constitutional draftsmanship and some historical materials, we are unpersuaded and believe this to be one of the unorthodox Crosskey theories that is unlikely ever to be adopted by the courts. It is an argument that not only demands that the subsequent course of constitutional development be ignored, but also depends entirely too much on Crosskey's general disparagement of and attempt to discredit The Federalist Papers, ${ }^{35}$ which are inconsistent with his thesis both in the aforementioned passages and in another in which Madison discussed the "republican form of government" clause. ${ }^{36}$

The uniqueness of the Crosskey thesis, it should be recognized, is in its view of

${ }^{20}$ Sce, e.g., I Joseph Story, Commentakies on the Constrturnon of THE UNuTEd States $\$ 586$ (5th ed. I89r); Charles Warken, The Making of the Constitution 403 (r937).

${ }^{80}$ ro8 Cong. Rec. 6678 (daily ed. April 26, I962) (remarks of Senator Johnston of South Carolina).

31 The Federalist No. 59, at 395; id. No. 6o, at 402 (Wright ed. 196I).

${ }^{32}$ Id. No. 52 , at 360 .

${ }^{a 3}$ I WillinM W. Crosskey, Polmitcs and the Constitution 53I-33 (r953).

st Id. at 522-39.

${ }^{35}$ See id. at 8-11.

so The Federalist No. 43 , at $31 \mathrm{I}-12$ (Wright ed. 196r). 
article I, coupled with article IV, as giving Congress authority to prescribe qualifications in state as well as federal elections. Indeed, in a variation on Crosskey's "tying clause" theme, one commentator on the literacy test legislation has expressed doubt about the constitutionality of limiting the legislation to federal elections in contravention of the requirement of article $I$, section 2 (and the seventeenth amendment) that qualifications for congressional voting be the same as those for voting for the most numerous branch of the state legislature. ${ }^{37}$ This contrasts sharply with the approach of the Department of Justice and other sponsors of S. 2750, who limited that bill to federal elections partly because they believed its constitutional support would thereby be buttressed by express and implied powers flowing from articles I añd II. Their theory more closely fits the pattern of currently fashionable notions of sophisticated federalism, with emphasis on the potency of Congress's peculiar interest in protecting and regulating the federal electoral process. Such general notions do not, however, negate the unfavorable historical materials concerning the meaning of "manner of holding elections" in article I, section 4, for purposes of relying on the express provisions of that section. It is true that some of the discussion contemporaneous with the adoption of the Constitution lends more support to this narrower idea of congressional protection of federal elections than to the Crosskey theme, ${ }^{38}$ and a few particularly favorable excerpts from the debates in the state ratifying conventions can be cited. ${ }^{30}$ But it must be kept in mind that support for almost any theory of constitutional interpretation can be found in those debates, partly because it is sometimes unclear whether objections raised to particular provisions were considered by the state convention to be accurate interpretations of provisions deemed acceptable or merely baseless distortions that the convention ignored. Moreover, the principal tenor of the debates seems more consistent with Hamilton's view, ${ }^{40}$. and there is the added circumstance that at the time they ratified the Constitution seven of the states expressed reservations about article $\dot{I}$, section 4 in the form of resolutions proposing that Congress's power to regulate the times, places, and manner of holding elections should exist only when a state neglected or refused to make the regulations necessary to allow national elections to be conducted. ${ }^{41}$

${ }^{37}$ Werdegar, supra note 24 , at 741-43, Hearings 612-13.

${ }^{88}$ See 5 Jonathan Elitiot, Debates on the Federal Constitution 40r-02 (2d ed. 1937) (remarks of Madison and King); The FedERALIST No. 59, at 394, 397-98 (Wright ed. 1961) (Hamilton).

${ }^{30}$ In the South Carolina convention, Charles Pinckney declared: "[I]t is absolutely necessary that Congress should have this superintending power, lest, by the intrigues of a ruling faction in a state, the members of the House of Representatives should not really represent the people of the state, and lest the same faction, through partial state views, should altogether refuse to send representatives of the people to the ǵeneral government." 4 ErLIoT, op. cit. supra note 38, at 303. See also 3 id. at 175-76 (remarks of Patrick Henry in the Virginia convention); 4 id. at 54 (remarks of Iredell in the North Carolina convention).

${ }^{\circ 0} \mathrm{See} 2$ id. at 49-5I (Massachusetts); .2 id. at 325-26 (New York); 3 id. at 8, 202-03 (Virginia); 4 id. at $6 \mathrm{I}, 65-67,7 \mathrm{I}$ (North Carolina). Even the Department of Justice memorandum admitted that "history provides inconclusive answers." Hearings 308.

${ }^{41}$ H.R. Doc. No. 398, 69th Cong.," Ist Sess. (I927) ("Documents Illustrative of the Formation of the Union of the American States") at ro18-19 (Massachusetts), r023 (South Carolina), r025 (New Hamp- 
Thus, article I, section 4, considered alone, is the flimsiest of foundations for supporting the literacy test legislation, and it is not without significance that even in its most expansive readings of that section the Supreme Court has not mentioned voting qualifications as among the permissible subjects of congressional legislation. ${ }^{42}$ The Court's only specific discussion of the article I, section 4 power in connection with voting qualifications is to be found in Minor $v$. Happersett, where, in holding that a state's denial of suffrage to women did not contravene the privileges and immunities clause of the fourteenth amendment, the Court incidentally mentioned $:^{43}$

It is not necessary to inquire whether this power of supervision thus given to Congress is sufficient to authorize any interference with the State laws prescribing the qualifications of voters, for no such interference has ever been attempted. The power of the State in this particular is certainly supreme until Congress acts.

Although the Justice Department claims support from the implications of this passage, ${ }^{44}$ it seems to us that if it has any significance at all it is to emphasize the Court's doubt that Congress is empowered under section 4 to interfere with stateprescribed voting qualifications.

Suggestions of a more promising constitutional theory to sustain the literacy legislation can be detected, however, in several other Supreme Court opinions, including two dealing with the article I, section 4 power. The earlier of these, Ex parte Siebold, ${ }^{45}$ sustained indictments of state officers for stuffing ballot boxes in congressional elections in violation of the extensive federal anti-election fraud legislation then in effect. ${ }^{46}$ In upholding Congress's power under article I, section 4, the Court said: $\mathbf{: t}^{47}$

It is the duty of the States to elect representatives to Congress. The due and fair election of these representatives is of vital importance to the United States. The government of the United States is no less concerned in the transaction than the State government is. It certainly is not bound to stand by as a passive spectator, when duties are violated and outrageous frauds are committed. It is directly interested in the faithful performance, by the officers of election, of their respective duties. Those duties are owed as well to the United States as to the State.

Even more suggestive is the following language from United States v. Classic, a I94I case in which the Supreme Court sustained federal indictments against state election officials for falsely counting and certifying ballots in a congressional primary: ${ }^{48}$

shire), 1033 (Virginia), 1039-40 (New York), r050 (North Carolina), r056-57 (Rhode Island). The Department of Justice takes comfort in the fact that the language of article I, section 4 was never revised despite these proposals. Hearings 310. But it seems to us that these reservations expressed by so many of the ratifying states, in the form of proposed amendments and otherwise, have strong persuasive value as to the proper interpretation of that provision even though no amendment was ever formally adopted.

. ${ }^{42}$.See Smiley v. Holm, 285 U.S. 355, 366 (I932).

$\therefore 68$ U.S. (2I Wall.) I62, I7I (I874).

"Hearings $3 \mathrm{Ir}$.

45 roo U.S. 371 ( 1880$)$.

60 This legislation, mostly long-since repealed, is summarized in Comment, 50 CaLIF. L. REv. 265, 269-70 (196i).

${ }^{47} 100$ U.S. at $388 . \quad \cdot \quad{ }^{48}$ 3 3 U.S. 299,315 (194I). 
While, in a loose sense, the right to vote for representatives in Congress is sometimes spoken of as a right derived from the states, [citations omitted] this statement is true only in the sense that the states are authorized by the Constitution, to legislate on the subject as provided by $\S 2$ of Art. I, to the extent that Congress has not restricted state action by the exercise of its powers to regulate elections under $\$ 4$ and its more general power under Article I, $\S 8$, clause 18 of the Constitution "to make all laws which shall be necessary and proper for carrying into execution the foregoing powers." See Ex parte Siebold, roo U.S. 37; Ex parte Yarbrough, supra, $66_{3}, 66_{4} \ldots$. .

The citation of Ex parte Yarbrough ${ }^{49}$ is significant in this context as indicative of the bridge between congressional power under article I, section 4 in combination with the necessary and proper clause, on the one hand, and, on the other, the implied power of Congress, apart from article I, section 4, to enact legislation for what is elsewhere in the Classic opinion called "protection of the integrity" of federal elections. ${ }^{\text {50 }}$ The Yarbrough case, which upheld the power of Congress to prohibit private persons from intimidating voters in congressional elections, is famous for its passage relying on implied "derivative" powers to counter the argument that Congress lacked expressed constitutional power to prevent such intimidation. ${ }^{51}$ A more recent case that is even more emphatic in its reliance on broad implied congressional power over the federal election process is Burroughs $\nu$. United States, ${ }^{52}$ which upheld the constitutionality of the Federal Corrupt Practices Act of I925. The act required the keeping of detailed accounts of contributions and the filing of statements with Congress by any organization that accepted contributions for the purpose of influencing or attempting to influence the election of presidential or vice presidential electors in two or more states; and the Court thus had to answer the contention that under article II, section I, the manner of appointment of presidential electors is expressly committed to the states and congressional authority is limited to prescribing "the time of chusing the Electors, and the Day on which they shall give their Votes. ..." The Court, relying on Yarbrough, responded $:^{53}$

While presidential electors are not officers or agents of the federal government ... , they exercise federal functions under, and discharge duties in virtue of authority conferred by, the Constitution of the United States. The president is vested with the executive power of the nation. The importance of his election and the vital character of its relationship to and effect upon the welfare and safety of the whole people cannot be too strongly stated. To say that Congress is without power to pass appropriate legislation to safeguard such an election from the improper use of money to influence the result is to deny to the nation in a vital particular the power of self-protection. Congress, undoubtedly, possesses that power, as it possesses every other power essential to preserve

10 I 10 U.S. 65 I (1884). ${ }^{50} 313$ U.S. at 319 .

5x "... [W] [Wat is implied is as much a part of the instrument as what is expressed. This principle, in its application to the Constitution of the United States, more than to almost any other writing, is a necessity, by reason of the inherent inability to put into words all derivative powers-a difficulty which the instrument itself recognizes by conferring on Congress the authority to pass all laws necessary and proper to carry into execution the powers expressly granted and all other powers vested in the government or any branch of it by the Constitution. Article I., sec. 8, clause I8." I10 U.S. at 658.

s2 290 U.S. 534 (1934).

${ }^{53}$ Id. at 545 . 
the departments and institutions of the general government from impairment or destruction, whether threatened by force or by corruption.

It is true that all of these cases involved what could be called extraneous corrupting influences rather than problems inherent in the state-prescribed voting qualifications themselves, but there is no compelling reason why a state's choice of qualifications should be immune from this congressional power to protect the integrity and representative character of the federal electoral processes. Surely Congress could find that process to be defiled and enact corrective legislation if a state were to impose such absurdly restrictive qualifications as a requirement of blue eyes, a college degree, ownership of an American-made car, or that the voter not be more than ten pounds overweight. Even if it is conceded that article I, section 4 was not intended to, and does not, give Congress power to alter voting qualifications, the question of implied power is still very comparable to that in Burroughs. This is true because under the prevailing view of article II the states reserved complete discretion over the manner of appointing presidential electors and are not compelled by the Constitution (and presumably cannot constitutionally be required by Congress) even to provide for their popular election rather than appointment by other means, ${ }^{54}$ yet Burroughs holds that Congress does have implied power to protect the integrity of the processes of popular election of presidential electors once that mode of selection has been chosen by the state.

Of course, it is arguable that literacy tests, unlike the hypothetical requirements discussed above or other corrupting influences, are rationally related to intelligent exercise of the franchise and should be considered an enhancement, or at least not a debasement, of the integrity of the election. ${ }^{55}$ In answer, it must first be said, in all candor, that this suggested distinction could possibly be accepted by the Court. But, as we shall later show, Congress could reasonably have concluded that the only substantial effect of its limited abolition of literacy and performance tests would be to curtail racial discrimination in federal elections, a form of discrimination that undeniably is constitutionally impermissible and debasing under the standards of the fourteenth and fifteenth amendments. In this respect, the argument in support of the legislation based on implied power to protect the purity of federal elections necessarily meshes with that based on Congress's fourteenth and fifteenth amendment power, as was saliently pointed out to the subcommittee in the following excerpt from the generally excellent Memorandum filed by the Department of Justice in the hearings: ${ }^{56}$

There is an obvious similarity between corruption of the Federal electoral process by the use of money and corruption of the same process by devices susceptible of being used and actually used to disenfranchise voters because of race. If anything, the latter is more

\footnotetext{
'See McPherson v. Blacker, 146 U.S. $1,27-36$ (r892); 2 STORX, op. cit. stupra note 29, at $\$ 1472$; WARREN, op. cit. supra note 29, at 622. Contra, I CROssker, op. cit. supra note 33, at 67-68.

${ }^{85}$ See Lassiter v. Northampton Election Bd., 360 U.S. 45, 5I-52 (1959).

${ }^{\circ}$ Hearings 3 I2.
} 
subject to congressional control for a number of reasons: $(I)$ it is directed toward a special class; (2) it is inconsistent with constitutional principles given express recognition in the I $4^{\text {th }}$ and I5th amendments; and (3) it is perpetrated by the State, or by State officials sworn to uphold the Constitution, rather than by private persons.

Unfortunately, the Justice Department was not content to rely only on the very tenable theory of implied power as its source of constitutional support supplementary to Congress's power to enforce the fourteenth and fifteenth amendments. In apparent preoccupation with the word "manner" in article I, section 4 and with the desire to bring the proposed legislation within that section's express terms, the Department added a confusing and ultimately unconvincing argument that the legislation would not really alter the qualifications required by the states but would merely change the manner of testing those qualifications. The ability to pass a literacy and comprehension test was generalized into a requirement of educational achievement that could equally well be met by the "more objective test" of possession of a sixthgrade diploma. As might be expected, the opponents had a field day pointing out the absurdity of claiming that every person who has ever completed the sixth grade will necessarily be found to possess (even at the time of schooling, let alone years later when he applies to vote) functional "literacy, and . . . a generalized familiarity with the civic order." The Attorney General's testimony before the subcommittee, in particular, was greatly weakened by the necessity of answering repeated questions about this subsidiary theory. ${ }^{58}$ Our own opinion is that this contention is about on a par with arguing that Congress would not be changing age qualifications if it were to decide that the age requirement is really a test of maturity and that anyone serving or having served in the armed forces should be considered sufficiently mature to vote and therefore cannot be barred from federal elections merely for having failed to reach a particular birthday anniversary. When it is remembered that under S. 2750 completion of six grades of schooling taught in the Spanish language in Puerto Rico would also be substituted for ability to pass an English literacy test, the speciousness of arguing that this is not a change in voting qualifications becomes all the more apparent. The only consideration that in our judgment keeps the argument from being entirely absurd is the fact that Congress could very well have concluded on the basis of the Civil Rights Commission's investigations and other evidence before $\mathrm{it}^{59}$ that the standard of literacy and comprehension actually being applied to white persons in all states is such that only a minuscule number of sixth-grade graduates (educated in English) are being disqualified on grounds other than race. But this aspect of the matter is much more directly related to Congress's powers to enforce the fourteenth and fifteenth amendments and does not really eliminate the logical difficulty with the argument that the legislation would not alter qualifications for voting.

In sum, it is our view that this legislation, as applied only to federal elections, is

${ }^{57}$ The quotation is from a letter in support of this theory from two law professors whose analysis is usually more discerning. Hearings $66_{4}$ (letter from Alexander M. Bickel and Louis H. Pollak).

${ }^{50}$ E.g., Hearings $28 \mathrm{I}-82$.

${ }^{50}$ See text at notes 66-70 infra. 
constitutionally sustainable under Congress's implied powers to protect the purity and integrity of the federal electoral process. The chief constitutional obstacle to such legislation if limited to federal elections is, in our opinion, the language of article I, section 2 (and the seventeenth amendment) saying that congressional electors "should have the Qualifications requisite for Electors of the most numerous Branch of the State Legislature." We believe that the Supreme Court would nevertheless hold that because of the primacy of Congress's interest in federal elections, its protective action can be limited to those elections even though its choice not to interfere similarly with state electoral processes results in some disparity between state and federal voting qualifications. Otherwise, the federal government would be constitutionally required to intervene in state electoral affairs in order to be able to afford protections it deems necessary for federal elections. This problem can be avoided entirely, however, by enactment of legislation covering both state and federal elections in reliance upon the fourteenth and fifteenth amendments. Since there is no need to reach actions of anyone but state officials, ${ }^{60}$ the limitation of these amendments to "state action" poses no problem.

\section{B. Power to Enforce the Fourteenth and Fifteenth Amendments}

In turning to consideration of Congress's powers to enforce the fourteenth and fifteenth amendments, ${ }^{61}$ a preliminary word will be said about inclusion in the discussion of the fourteenth amendment and cases decided under that amendment. The opponents of the legislation have argued that despite the broad wording of the privileges and immunities, due process, and equal protection clauses, none of these provisions in section I of the fourteenth amendment can properly be considered to forbid state discrimination in denying the right to vote. Not only would this render the fifteenth amendment mere surplusage, the argument goes, but it would be inconsistent with section 2 of the fourteenth amendment which recognized the "right" of the states to so discriminate and provided for proportional reduction of the state's congressional representation to be imposed as redress, and presumably the only permissible form of redress absent the fifteenth amendment. Although this argument commands some historical support, ${ }^{62}$ it seems futile in the face of Supreme Court decisions that have relied squarely and solely on the fourteenth amendment in striking down state discrimination in the electoral process. ${ }^{63}$ Thus,

${ }^{\circ} \mathrm{S}$. 2750 also contains a provision that would amend existing statutory prohibitions imposed upon private conduct, but the amendment does not in itself raise any novel question of constitutionality. For discussion of the constitutionality of these prohibitions, as they would be amended, see Hearings 595-96 (letter from Douglas B. Maggs).

${ }^{21}$ Dean Griswold has suggested that power to enforce the thirteenth amendment is also relevant in dealing with this "vestige of slavery," Hearings $\mathrm{II} 7-18$, but this does not seem to us to add anything significant to Congress's ample power under the fourteenth and fifteenth amendments.

${ }^{82}$ See Cong. Globe, 40th Cong., 3d Sess. 1003 (r869) (remarks of Senator Howard); United States v. Reese, 92 U.S. 214, 217-18 (1876) (dictum); Minor v. Happersett, 88 U.S. (2I Wall.) 162, 174 (1874) (dictum).

${ }^{63}$ Nixon v. Condon, 286 U.S. 73 (I932); Nixon v. Herndon, 273 U.S. 536 (I927); cf. Baker v. Carr, 369 U.S. 186 ( 1962 ). 
while we believe that the fifteenth amendment alone is a sufficient source of congressional power to enact the literacy legislation, the fourteenth amendment also can appropriately be looked to and, in our judgment, decisions interpreting either of the almost identically worded congressional enforcement provisions of the two amendments can, in any event, be considered fungible for this purpose and will be treated as such in the remainder of this article.

The main line of opposition defense against the asserted fourteenth and fifteenth amendment power is based on a states' rights oriented, circumscribed view of what is constitutionally "appropriate legislation" for the enforcement of those amendments. The argument is that, unlike the positive regulatory powers of Congress that are buttressed by broad implied powers under the "necessary and proper" clause to help effectuate desired federal control over areas of primarily federal concern, the power to enforce the prohibitions of the fourteenth and fifteenth amendments is a negative power that arises only when the states have actually violated those prohibitions. Its exercise thus must be confined to coextensivity with such violations; otherwise, under the guise of such power, Congress would be invading areas constitutionally left to the discretion of the states. As Senator Ervin put it in the hearings, literacy test requirements have been held by the Supreme Court, in response to challenges based on the fourteenth and fifteenth amendments, to be valid on their face; therefore Congress cannot adopt legislation to nullify such requirements even though it concludes that such tests are susceptible of discriminatory application and are in fact being wrongfully applied to accomplish the discriminations forbidden by those two amendments. Congress's corrective legislation, in his view, must be designed to prevent such wrongful application by means which leave the underlying state-adopted standard intact. $^{64}$ Otherwise, it is argued by another opponent of the legislation, Congress would be operating on a novel theory of the fourteenth and fifteenth amendments which would be the death knell of our federalism because it could be used to abolish any state legislation that Congress thinks is being applied by one of the states so as to deprive persons of equal protection of the laws or otherwise violate one of the prohibitions of those amendments: ${ }^{65}$

It would make no difference, if this is the law, what State or how many States had used the law discriminatingly, or, in the language of the Constitution, so as to deprive persons within its jurisdiction of the equal protection of the laws.

If the State of California, for example, in the opinion of Congress, used its capital punishment statute so as to deny persons within its jurisdiction of the equal protection of it, that is, if more Chinese or Negroes were executed than white people, then the Congress could supersede the statutes of all States prescribing capital punishment.

The short answer to this argument (and its attendant parade of horrors) begins with recognition that it consists merely of abstract and formalistic concepts of federalism far removed from the factual context of the proposed literacy legislation and its predictable effects, and thus far removed from the considerations that are

"Hearings 228.

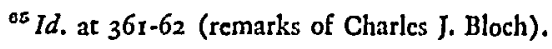


crucial in the very particularistic process of constitutional adjudication characteristic of the modern Supreme Court. The very heart of the matter was exposed in the Attorney General's testimony before the subcommittee that in actual practice "virtually no one with [a sixth-grade] ... education has been turned down as a voter for other than racial reasons." ${ }^{166}$ While it would be an onerous and almost impossible task to conclusively verify such a statement, the Department of Justice did submit to the subcommittee some substantiation in addition to the impressive findings of the Civil Rights Commission ${ }^{67}$ and of previous studies dealing with practices in the Southern states. ${ }^{68}$ The Department secured this additional information by asking public officials in each of the thirteen non-Southern states using literacy tests what effect the sixth-grade standard of the proposed legislation would have on eligibility to vote in their states. The replies uniformly express the opinion that virtually all persons with a sixth-grade education have been and would be able to satisfy the literacy tests in these states, ${ }^{69}$ and in several instances the correspondent even revealed further that the literacy test simply "has not been in recent years and is not at the present time a factor in voting" in the state ${ }^{70}$ (which may, incidentally, help to explain why the majority of the states have been content to qualify voters without any literacy requirement at all). Thus, a true perspective emerges for protestations that the legislation would interfere with the prerogatives of forty-four innocent states to prescribe such literacy requirements as they see fit merely because of instances of discriminatory administration found by the Civil Rights Commission in only six states. ${ }^{71}$ This amounts to an assertion that, in deference to the remote possibility that some state might (in perverse contradiction of the historic trend in this country toward more universal suffrage) suddenly decide to reverse itself and impose stringent advanced literacy requirements, Congress must be held powerless to adopt what it considers an effective and easily administrable means to combat existing serious and widespread denials of fundamental constitutional rights even though with good reason $^{72}$ it considers alternative measures inadequate to expeditiously eradicate these violations of rights it is duty-bound to protect. This is enervation to no useful purpose of Congress's constitutional power to protect civil rights-surely the very antithesis of enlightened federalism. ${ }^{73}$

There is also a lengthier answer, which can begin with examination of a passage that the opponents often quote in support of their narrow view of congressional power. In the famous Civil Rights Cases of 1883 , the Supreme Court said that the "legislation which Congress is authorized to adopt" pursuant to its enforcement power in section five of the fourteenth amendment, ${ }^{74}$

${ }^{\circ} \mathrm{Id}$. at 264 .

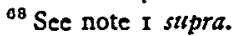

${ }^{6 r}$ See text at note I supra.

${ }^{70}$ Id. at $3 \times 9$ (Delaware); see id. at 316 (Alaska), 3r9-20 (Maine), 324 (Washington).

${ }^{71}$ E.g., id. at 280 (Senator Ervin).

${ }^{73} \mathrm{Cf}$. Note, $46 \mathrm{MINN}$. L. REv. I076, ro8 (1962) (reaching a similar conclusion by "balancing" the state's interest in disqualifying illiterates against the federal interest in preventing discrimination).

7t 109 U.S. 3, I3-14 (1883). (Emphasis added.) 
is not general legislation upon the rights of the citizen, but corrective legislation, that is, such as may be necessary and proper for counteracting such laws as the States may adopt or enforce, and which, by the amendment, they are prohibited from making or enforcing, or such acts and proceedings as the States may commit or take, and which, by the amendment, they are prohibited from committing or taking.

The first thing to be said about this language is that it was written in the context of differentiating Congress's power to correct discriminatory action by the states from its asserted power, which the Court denied, to forbid discriminations by private persons. It can be misleading, therefore, to try to read into this language an attempt to circumscribe the way in which Congress can use its granted power to counteract forbidden discriminations that do emanate from the states. ${ }^{75}$

Secondly, it should be noted that the Court, in the italicized language at the end of the quotation, explicitly recognized that the prohibitions of the fourteenth amendment extend to discriminatory administration of state law regardless of whether the underlying state statute is valid on its face. This was clearly established just three years later in the leading case of Yick Wo v. Hopkins, ${ }^{70}$ in which the Supreme Court held that a Chinese alien was unconstitutionally denied equal protection of the laws where the practice of a local board of supervisors, in administering a municipal ordinance that prohibited the operation of laundries in other than brick or stone buildings without the board's prior consent, was to deny its consent to all Chinese aliens while granting its consent to all others.

Though the law itself be fair on its face and impartial in appearance, yet, if it is applied and administered by public authority with an evil eye and an unequal hand, so as practically to make unjust and illegal discriminations between persons in similar circumstances, material to their rights, the denial of equal justice is still within the prohibition of the Constitution. ${ }^{77}$

This principle has been applied by the Court to strike down the underlying provision of state law as unconstitutional in a case involving a state constitutional amendment changing registration requirements so that only persons who could "understand and explain any article of the constitution of the United States" could be registered as voters, an amendment found by the Court to be racially discriminatory in both purpose and administration. ${ }^{78}$ The Supreme Court there cited and relied upon both Yick Wo and Lane v. Wilson, the famous case striking down the revised version of Oklahoma's grandfather clause, in which it was said that "the [Fifteenth] Amendment nullifies sophisticated as well as simple-minded modes of discrimination. It hits onerous procedural requirements which effectively handicap exercise of the franchise

\footnotetext{
${ }^{75}$ In the very next two sentences following the above quotation, the Court said: "It is not necessary for us to state, if we could, what legislation would be proper for Congress to adopt. It is sufficient for us to examine whether the law in question is of that character." Id. at $\mathrm{r}_{4}$.

${ }_{70} 118$ U.S. 356 (1886).

${ }^{77}$ Id. at $373-74$.

${ }^{78}$ Schnell v. Davis, 336 U.S. 933, affirming per curiam 81 F. Supp. 872 (S.D. Ala. 1949).
} 
by the colored race although the abstract right to vote may remain unrestricted as to race."70

A third, and very important, point to keep in mind is that many of the cases decided under the fourteenth and fifteenth amendments, including those discussed in the preceding paragraph, have involved instances in which remedies for alleged state infractions of the constitutional standards were requested from the federal courts even though Congress had not exercised its constitutional power to take responsive corrective action. There is no reason to assume that such cases, which are concerned with the propriety or impropriety of judicially created remedies in various circumstances, necessarily delimit Congress's discretion in fashioning "appropriate legislation" to combat forbidden state discriminatory practices. ${ }^{80}$ Indeed, the use of the words "necessary and proper" as synonymous with "appropriate" in the above quotation from the Civil Rights Cases suggests that Congress's enforcement power under the fourteenth and fifteenth amendments is to be construed as broadly as Congress's other powers, buttressed by the sweeping "necessary and proper" clause of article $\mathrm{I}$, section $8,{ }^{81}$ have been construed ever since the $\mathrm{I} 8 \mathrm{rg}$ decision in $M^{\prime}$ Culloch v. Maryland. ${ }^{82}$ We need not rely, however, on surmise based on the use of this phrase in the Civil Rights Cases because three years earlier the Court, in upholding the constitutionality of a portion of the Civil Rights Act of 1875 , spoke more explicitly of the provisions empowering Congress to enforce the thirteenth, fourteenth, and fifteenth amendments by appropriate legislation $:^{83}$

All of the amendments derive much of their force from this latter provision. . . . Congress is authorized to enforce the prohibitions by appropriate legislation. Some legislation is contemplated to make the amendments fully effective. Whatever legislation is appropriate, that is, adapted to carry out the objects the amendments have in view, whatever tends to enforce submission to the prohibitions they contain, and to secure to all persons the enjoyment of perfect equality of civil rights and the equal protection of the laws against State denial or invasion, if not prohibited, is brought within the domain of congressional power.

This broad view of the congressional enforcement power is especially important because in cases challenging federal legislation for alleged incursion on areas of

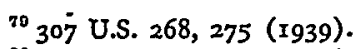

${ }^{80}$ There is a suggestive analogy in the well-established power of Congress under the commerce clause to pre-empt state laws dealing with interstate commerce even though, in the absence of congressional legislation, the Supreme Court might not consider the particular state law a violation of the negative implication of the commerce clause. See, e.g., South Carolina Highway Dep't v. Barnwell Bros., 303 U.S. I77 (1938). For recognition of this principle in the literacy test context, see Lassiter v. Northampton Election Bd., 360 U.S. 45, 5 I (1959).

${ }^{82}$ There is nothing in the language of the Constitution to suggest that the necessary and proper clause does not itself apply to congressional power to enforce the fourteenth and fifteenth amendments, just as it does to all other powers.

${ }^{82} 17$ U.S. (4 Wheat.) 316 ( 1819 ).

${ }^{88}$ Ex parte Virginia, roo U.S. $339,345-46$ ( 1880 ). This is fully comparable to the famous formulation in M'Culloch $v$. Maryland: "Let the end be legitimate, let it be within the scope of the constitution, and all means which are appropriate, which are plainly adapted to that end, which are not prohibited, but consist with the letter and spirit of the constitution, are constitutional." 17 U.S. (4 Wheat.) at 421 . 
authority constitutionally reserved to the states decision turns almost exclusively, as it must under the supremacy clause of article VI, on whether there is a constitutional source of power to support the action of Congress. The approach of the courts to such constitutional issues was carefully spelled out by the Supreme Court just fifteen years ago: ${ }^{84}$

The powers granted by the Constitution to the Federal Government are subtracted from the totality of sovereignty originally in the states and the people. Therefore, when objection is made that the exercise of a federal power infringes upon rights reserved by the Ninth and Tenth Amendments, the inquiry must be directed toward the granted power under which the action of the Union was taken. If granted power is found, necessarily the objection of invasion of those rights, reserved by the Ninth and Tenth Amendments, must fail.

This basic approach, combined with the modern Supreme Court's deferential and expansive view of congressional powers, largely accounts for the fact that, as Professor Sutherland pointed out in his letter to the subcommittee, in the past twentyfive years only seven federal statutes have been held unconstitutional by the Supreme Court and in each of these instances the issue was one of incursion on individual rights or liberties rather than interference with states' rights. ${ }^{85}$ Moreover, other decisions of the Supreme Court during this period demonstrate that the exercise of congressional power will be upheld even though it interferes with and supersedes state policy as to matters intimately and traditionally the concern of the states and, at least in some instances, almost surely not themselves subject to direct congressional regulation. As recently as May I96I, for example, it was held that a state's power to control the devolution of personal property upon death of one of its residents must give way to a federal statute providing for escheat to the federal government of personal property of a veteran who dies in a veterans' hospital without leaving a will or legal heirs. ${ }^{86}$ The Court disposed of the constitutional challenge to the statute in one short paragraph, ${ }^{87}$ despite the very attenuated need for this means of support of services to veterans in order to effectuate Congress's "powers to raise armies and navies and to conduct wars" relied on by the Court. Equally graphic examples are cases holding that in pursuit of its powers to conduct investigations, Congress may effectively bar the use of testimony it subpoenas in state criminal proceedings, ${ }^{88}$ and in support of the investigative power of federal grand juries, even grant witnesses immunity from state prosecution for state crimes concerning which

84 United Public Workers v. Mitchell, 330 U.S. 75, 95-96 (1947). Sce also Ex parte Virginia, 100 U.S. 339, 346 ( 1880 ) (adopting same approach to congressional power to enforce fourtenth amendment).

${ }^{85}$ These seven instances are summarized by Professor Sutherland in Hearings 63r. The same summary also appears in Paul A. Freund, Arthur E. Sutherland, Mark DeWolfe Howe \& Ernest J. Brown, ConstTtutionat Law 2i (2d ed. rg6r).

${ }^{88}$ United States v. Oregon, 366 U.S. 643 (1961); cf. Kolovrat v. Oregon, 366 U.S. I87 (196I).

${ }^{87} 366$ U.S. at 648-49.

ss Adams v. Maryland, 347 U.S. I79, 183 (1954) (saying "state courts are bound" by the federal statute "even though it affects their rules of practice"). 
they have been compelled to testify in the federal investigation. ${ }^{89}$. Other examples could be added to the discussion, ${ }^{90}$ but these suffice to show that the primacy of state interest in the subject matter, or even the constitutional reservation to the states of power over that subject matter, does not mean that it is an area immune from being affected by the exercise of powers that have been delegated to Congress. There is no reason to doubt that this statement applies to Congress's power to enforce the fourteenth and fifteenth amendments as well as to other powers, as is shown by the Supreme Court's recent holding that state power to describe the boundaries of municipal corporations within the state cannot, even in the absence of federal legislation, be exercised in violation of fifteenth amendment prohibitions. ${ }^{91}$

Nor is congressional power defeated by the fact that the congressionally imposed sixth-grade criterion might possibly enfranchise a few persons who would otherwise have been eliminated on nonracial grounds by fairly administered literacy tests. It is well settled that a legislative scheme designed to achieve a valid congressional purpose can embrace a "penumbra" of prohibitions which, considered alone, would be beyond congressional power to enact. The leading modern case on the subject is United States $v$. Darby, ${ }^{92}$ in which the Supreme Court upheld the constitutionality of the Fair Labor Standards Act of 1938. A unanimous Court, speaking through Mr. Justice Stone, rejected objections based on the extent to which regulation of intrastate activity would be entailed: $:^{93}$

Congress, having by the present Act adopted the policy of excluding from interstate commerce all goods produced for the commerce which do not conform to the specified labor standards, it may choose the means reasonably adapted to the attainment of the permitted end, even though they involve control of intrastate activities. Such legislation has often been sustained with respect to powers, other than the commerce power granted to the national government, when the means chosen, although not themselves within the granted power, were nevertheless deemed appropriate aids to the accomplishment of some purpose within an admitted power of the national government.

Myriad other applications of this "penumbra" doctrine are cited in Darby ${ }^{\text {94 }}$ and ably discussed in one of the student comments on the literacy test legislation. ${ }^{95}$ We need here repeat only a sentence from a page of an earlier opinion specifically cited in Darby: $:^{06}$

${ }^{80}$ Reina v. United States, 364 U.S. 507, 51 r-12 (1960); Ullmann v. United States, 350 U.S. 422, 43436 (1956). See also Brown v. Walker, 161 U.S. 59r (r896).

${ }^{00}$ See, e.g., Testa v. Katt, 330 U.S. 386 (1947); Case v. Bowles, 327 U.S. 92, 102 (1946).

${ }^{02}$ Gomillion v. Lightfoot, 364 U.S. 339 ( 1960 ). "When a State exercises power wholly within the domain of state interest, it is insulated from federal judicial review. But such insulation is not carried over when state power is used as an instrument for circumventing a federally protected right." $1 d$. at 347 . See also Reina v. United States, 364 U.S. 507, 5 Ir $(\mathrm{x} 960)$ (alleged "distinctions based upon the particular granted power concerned have no support in the Constitution").

${ }_{03}^{03} 312$ U.S. 100 ( $194 \mathrm{I}$ ).

${ }^{04}$ ld. at $121-22$.

ov Comment, 50 Calif. L. Rev. 265, 279-80 (1962). See also Railroad Comm'n of Wisconsin v. Chicago B. \& Q.R.R., 257 U.S. 563,588 (1922).

${ }^{00}$ Purity Extract Co. v. Lynch, 226 U.S. I92, 201 (1912) (emphasis added), cited in 312 U.S. at I2I. 
It does not follow that because a transaction separately considered is innocuous it may not be included in a prohibition the scope of which is regarded as essential in the legislative judgment to accomplish a purpose within the admitted power of the Government.

Thus, inclusion of a "penumbra" area in the regulatory scheme is among the matters of congressional discretion to which the courts will defer.

The scope of Congress's discretion in deciding upon means to attain constitutionally permissible ends was well described by the Supreme Court in one of the important cases dealing with congressional regulation of voting: ${ }^{97}$

The power of Congress to protect the election of President and Vice President from corruption being clear, the choice of means to that end presents a question primarily addressed to the judgment of Congress. If it can be seen that the means adopted are really calculated to attain the end, the degree of their necessity, the extent to which they conduce to the end, the closeness of the relationship between the means adopted and the end to be attained, are matters for congressional determination alone.

From the beginning, the Court has indicated a like attitude toward Congress's power to enforce the fourteenth and fifteenth amendments, ${ }^{98}$ and only recently the Court has once again forcefully reiterated this basic approach in sustaining the exercise of congressional power against claims of states' rights. ${ }^{09}$ While the Court will depart from this deferential approach to assure that even a "legitimate and substantial" governmental purpose is not "pursued by means that broadly stifle fundamental personal liberties when the end can be more narrowly achieved,"100 it has made clear that such cases are to be distinguished from those "involving different constitutional issues" in which "more administrative leeway has been thought allowable in the interest of increased efficiency in accomplishing a clearly constitutional central purpose."101 The proposed literacy legislation plainly falls in the latter category, since it can be attacked only for alleged infraction of states' rights, rather than of individual rights or liberties. ${ }^{102}$

In the path of this tide of constitutional jurisprudence, the opponents place their reliance on a few early cases holding legislative provisions enacted by Congress shortly after the passage of the fifteenth amendment unconstitutional for attempting to penalize voting discriminations based on factors other than race or color ${ }^{103}$ or for

${ }^{\text {} 7}$ Burroughs v. United States, 290 U.S. 534, 547-48 (r934).

${ }^{88}$ See Virginia v. Rives, 100 U.S. 313, 318 (1880).

98 "The grant of both federal and state immunity is conducive to that end, and that is enough. Even if the grant of immunity were viewed as not absolutely necessary to the execution of the congressional design, '[T]o undertake here to inquire into the degree of . . necessity, would be to pass the line which circumscribes the judicial department, and to tread on legislative ground.' McCulloch $v$. Maryland, 4 Wheat. 316, 423." Reina v. United States, 364 U.S. 507, 512 (1960).

${ }^{100}$ Shelton v. Tucker, 364 U.S. 479,488 (r960); see, e.g., Talley v. California, 362 U.S. 60 (1960); Cantwell v. Connecticut, 3 Io U.S. 296 (1940); Lovell v. City of Grifin, 303 U.S. 444 (1938).

101 Shelton v. Tucker, 364 U.S. 479,488 n.8 (1960).

${ }^{102} \mathrm{Cf}$. text at note 85 supra.

${ }^{108}$ United States v. Reese, 92 U.S. $21_{4}$ (1875). But cf. United States v. Raines, 362 U.S. 17 ( 1960 ) (declining to follow Reese approach in upholding constitutionality of provisions of Civil Rights Act of 1957 as applied to state official). 
encompassing discriminatory action by private individuals as well as by states. ${ }^{104}$ But, as Professor Heyman correctly pointed out in an article published prior to the subcommittee's hearings, ${ }^{105}$ these decisions were based not on a conclusion that Congress had adopted constitutionally impermissible means to combat discriminations forbidden by the Constitution but rather on a finding that the end purposes of the legislation were beyond Congress's constitutional powers. Since it is incandescently clear that the current legislative proposals are designed to eliminate racial discrimination by state officials, ${ }^{106}$ these decisions are simply inapposite to determination of the only relevant constitutional question, namely, whether as a means chosen by Congress to accomplish this indisputably constitutional objective the legislation would be within the range of congressional discretion as "appropriate" to enforcement of the fourteenth and fifteenth amendments. Given the inclusion by Congress of the sixth-grade criterion to minimize, if not eliminate, the impact of the antiliteracy test legislation on all existing state practices except those that are in fact racially discriminatory, it is inconceivable to us that the Supreme Court would turn its back on the teaching of the many decisions discussed above in order to hamstring Congress in its choice of effective remedies for the protection of a category of individual rights toward which the Court itself has been notably solicitous in recent years.

\section{Subsidiary (and Largely Frivolous) Constitutional Objections}

Several subsidiary constitutional objections raised during consideration of the bills are not serious enough to require lengthy refutation and hence will be discussed rather briefly.

The bills' introductory recitals of congressional findings that literacy tests are being used to accomplish racial discrimination were repeatedly attacked in the debates as unconstitutional attempts to have Congress make factual determinations that can constitutionally be made only by the courts. ${ }^{107}$ It is simply absurd thus to argue, in effect, that Congress must legislate in ignorance and that the many hearings and other factual investigations it conducts are meaningless; and the fact is that recitals of Congress's findings are a commonplace feature in federal statutes. ${ }^{108}$ Their use was specifically recognized and upheld by the Supreme Court in the famous filled milk case as no "more than a declaration of the legislative findings deemed to support and justify the action taken as a constitutional exertion of the legislative power, aiding informed judicial review, as do the reports of legislative committees, by revealing the rationale of the legislation." 109 Whether set forth in statutory

104 James v. Bowman, I90 U.S. I27 (1903); of. United States v. Harris, 106 U.S. 629 (1883).

${ }^{105}$ Heyman, supra note 14 , at 198 .

${ }^{200}$ This is indicated throughout the hearings and debates, as well as by reference to the Civil Rights Commission Report, see notes $\mathrm{I}-2$ supra, and the recitals in the bills themselves.

${ }^{107}$ E.g., 108 CoNG. REC. 6997 (daily ed. May 2, 1962) (remarks of Senator Robertson of Virginia); I08 CoNG. REc. 7460 (daily ed. May 9, 1962) (remarks of Senator Case of South Dakota).

${ }^{108}$ It was pointed out during the hearings, for example, that "all three of the major labor bills enacted by Congress in the last 30 years, the Wagner Act, the Taft-Hartley Act, and the LandrumGriffin Act, begin with recitals of findings and policies." Hearings 219 (statement of Thomas Harris).

${ }^{200}$ United States v. Carolene Prods. Co., 304 U.S. I44, I52 (r938). 
recitals or elsewhere, such congressional findings, while not conclusive on the courts as factual determinations, ${ }^{110}$ will be respected by them as indicating the factual understanding upon which Congress acted. ${ }^{111}$ There is no need, however, for the underlying factual premises of congressional action to be set forth in any particular way or even to be precisely formulated since, as one commentator has put it, "there is common agreement that a court normally examines legislative facts not to determine their 'truth,' but to determine whether a reasonable legislative judgment could have been made supporting the statute in its enacted form."112

Another obfuscating factor in the Senate's deliberations was the repeated emphasis by Senator Ervin on the fact that all instances of racially discriminatory application of literacy test requirements by state officials are presumably violations of state law. ${ }^{113}$ Whatever may be the persuasive value of this as an argument addressed to Congress's discretion (and we think it eminently unpersuasive as a reason for shirking congressional responsibility to protect federal constitutional rights that state authorities are in fact nullifying), it is clearly settled that as a constitutional matter Congress has power to enforce the fourteenth and fifeenth amendments against "every state official .... without regard to other authority in the State that might possibly revise their actions" and it "makes no difference that the discrimination in question, if state action, is also violative of state law."114

A third distraction was comment directed to the fact that the proponents of the literacy test bills were arguing that their objective was within Congress's legislative power even though the same Congress had accepted the route of constitutional amendment as the appropriate way to eliminate the poll tax requirement from federal elections. In a letter to the subcommittee, one prominent constitutional law authority said he found this situation "somewhat anomalous" because he "fail[ed] to see such substantial differences between the two types of qualifications as to warrant such different conclusions on the question of constitutional power in Congress to deal with these matters."115 An obvious difference, it seems to us, is that literacy test requirements are susceptible of being administered, and are in fact being administered, in a racially discriminatory manner, while poll taxes do not seem to be, and were not demonstrated to Congress to be, comparably susceptible of discriminatory administration. With both proposals limited as they were to federal elections, however, there may be some comparability in the poll tax's conduciveness to vote buying and similar corrupting influences, ${ }^{110}$ although the differ-

\footnotetext{
${ }^{210}$ See, e.g., Chastleton Corp. v. Sinclair, 264 U.S. 543, 547-49 (1924).

${ }^{111}$ See, e.g., Communist Party of the United States v. Subversive Activities Control Bd., 367 U.S. I, 93-97 (I96r); Nebbia v. New York, 291 U.S. 502, 516-r8, 530 (1934).

${ }_{12}$ Karst, Legislative Facts in Constitutional Litigation, 1960 Sup. Cr. REv. 75, 84-85.

${ }^{113}$ E.g., Hearings 270, 477-78.

${ }^{124}$ United States v. Raines, 362 U.S. 17, 25 (1960); accord, Monroe v. Pape, 365 U.S. 167, 171-72, 183 (rg6r).

${ }_{215}$ Hearings 640 (letter from Paul G. Kauper).

${ }^{110}$ For comprehensive studies, see Christensen, The Constitutionality of National Anti-Poll Tax Bills, 33 Minn. L. REv. 217 (I949); Kallenbach, Constitutional Aspects of Federal Anti-Poll Tax Legislation, 45 Mich. L. Rev. 7I7 (x947).
} 
ence in apparent applicability of the fourteenth and fifteenth amendment enforcement power remains. The more basic answer, though, is that Congress is free to decide, whether because its factual information is limited or for whatever reasons it chooses, to propose a constitutional amendment even though it could have accomplished the same objective through legislation, and it is not thereby estopped from enacting comparable or even identical legislation within its existing constitutional power.

Finally, the inclusion in S. 2750's sixth-grade criterion of education in Puerto Rico, even though in the Spanish language, raised special objections. There was support from some academic commentators ${ }^{117}$ for the argument that the "equal protection" aspect of the fifth amendment's due process clause ${ }^{118}$ would not permit such federal rights to be extended to these Spanish-reading citizens if not also extended to citizens literate in the other foreign languages in which news media are published in this country. But there are reasons for special congressional concern about the rights of these particular Spanish-speaking citizens, including the fact that their education in Puerto Rico was conducted in Spanish under the sponsorship of the United States, the existence of express constitutional power in Congress to "make all needful Rules and Regulations respecting the Territory or other Property belonging to the United States,"119 the recognition of implied congressional power to legislate with respect to American Indians and, presumably, other persons entitled to the special protection of the federal government, ${ }^{120}$ and the stipulation in the Treaty of Paris between the United States and Spain of 1899 that "the civil rights and political status of the native inhabitants of [Puerto Rico] . . shall be determined by the Congress."121 In our opinion, it misconceives the deferential approach of the modern Supreme Court toward discretion in legislative classification ${ }^{122}$ to contend that the Court would strike down as invidiously discriminatory against others the singling out of this group, on the basis of the above important and distinctive considerations, for special federal protection or benefit. After all, Congress would in no way be preventing the states from affording similar voting privileges to other foreign language groups, nor would it be depriving those groups of any advantages or immunities they would have absent the federal legislation.

The more serious problem raised by inclusion of the Puerto Rican provision is that this feature goes far beyond the remainder of the proposed legislation in displacing state judgment as to voting qualification requirements by equating literacy in Spanish with literacy in English. While we think it entirely possible that the

${ }^{117}$ Hearings 579, 648 (letters from Alfred Avins and Charles L. Crum); accord, id. at 32 (statement of Senator Ervin).

${ }^{118}$ See Bolling v. Sharpe, 347 U.S. 497 (I954); cf. Hurd v. Hodge, 334 U.S. 24 (I948).

${ }^{110}$ U,S. Const. art. IV, $\$ 3$, cl. 2.

${ }^{120}$ See, e.g., United States v. Nice, $24 \times$ U.S. 591 (19r6); United States v. Kagama, II 8 U.S. 375 (1886); $c f$. Balzac v. Porto Rico, 258 U.S. 298, 308 (1922) (dictum). See generally Magruder, The Commoniuealth Status of Puerto Rico, 15 U. PITT. L. REv. I (1953).

121 30 Stat. 1754, r759. Compare Missouri v. Holland, 252 U,S. 4 I6 (r920) (reserved power), with Reid v. Covert, 354 U.S. I (I957) (express prohibition).

122 See, e.g., McGowan v. Maryland, 366 U.S. 420, 425-26 (Ig6I); Williamson v. Lee Optical, Inc., 348 U.S. 483,489 (I955). 
Supreme Court would uphold such a legislative provision as an allowable judgment by Congress that Spanish-speaking citizens educated in Puerto Rico should not be classed with illiterates, ${ }^{123}$ particularly if the legislation is limited to federal elections, ${ }^{124}$ we think that the constitutionality of this part of S. 2750 is so much less certain than that of the remainder that it was a serious tactical error on the part of administration forces to include the Puerto Rican feature in the bill even though it might be separately reviewable under the bill's severability clause. After all, a person denied the ballot on the basis of illiteracy in English can much more readily cure his defect than can one denied on the basis of his skin color; and with instruction in English now required in the Puerto Rican elementary schools, ${ }^{125}$ Congress could well have regarded the problem as a temporary one that could adequately be met by adding an appropriate cut-off date, assuring instruction in English, to the inclusion in the bill's standards of a sixth-grade Puerto Rican education.

III

\section{Evaluation}

The opponents of the literacy legislation are, in a sense, to be congratulated for getting phenomenal mileage out of a lame assortment of frivolous and near-frivolous constitutional contentions. The lengthy senatorial debating efforts in this constitutional wonderland seem to us, however, to have been a poor substitute for the kind of constructive, responsible work that Congress might have accomplished, in far less time, in response to the underlying problem of misuse of literacy tests. Scant, if any, attention was given to problems of draftsmanship or to possibilities of strengthening the legislation's constitutional underpinning by modification of minor provisions such as the one relating to Puerto Rican education. Even more basic was failure to consider alternative solutions that might be more thoroughly effective and more easily administrable than the sixth-grade criterion. Several Senators, both Southern and non-Southern, expressed misgivings during the debate that the bill might actually do more harm than good to Negro voting efforts. ${ }^{128}$ While we think some of these fears may have been exaggerated or founded on misunderstanding of the bill's provisions, ${ }^{127}$ we agree with the critics that many prospective voters probably would not

${ }^{123}$ Cf. Meyer v. Nebraska, 262 U.S. 390 (I923). But see 108 Conc. Rec. 6997 (daily ed. May 2, 1962) (remarks of Senator Robertson of Virginia emphasizing that adequate Spanish-language news sources are not available with respect to elections in many areas of the United States).

124 Cf. text at notes $45-56$ supra.

${ }^{125}$ Hearings 168 (memorandum of U.S. Commission on Civil Rights); cf. 66 Stat. 239 (1952), 8 U.S.C. $\$$ I $_{43}$ (1958) (adding as a requirement for naturalization-not applicable to Puerto Ricans, who have the status of citizens- "an understanding of the English language, including an ability to read, write, and speak words in ordinary usage in the English language").

${ }^{120}$ E.g., 108 CoNG. Rec. 6713 (daily ed. Apr. 27, r962) (Senator Ervin of North Carolina); 108 Conc. Rec. 7333 (daily ed. May 8, 1962) (Senator Robertson of Virginia); ro8 Conc. Rec. 7559 (daily ed. May 10, 1962) (Senator Bartlett of Alaska, particularly fearing the consequences of a decision of unconstitutionality). But cf. Hearings 486-503 (statement by Roy Wilkins in support of the proposed legislation on behalf of NAACP and member organizations of the Leadership Conference on Civil Rights).

${ }^{227}$ Sec, e.g. 108 CoNG. REc. 6787 (daily ed. Apr. 30, 1962) (Senator McClellan of Arkansas, arguing 
have documentary proof of successful completion of the sixth grade and therefore might still be eliminated through improper administration of literacy tests after their unsupported assertions about their schooling were rejected by the registrars. If the legislation is to be limited to federal elections anyway, it would probably be much more effective to follow earlier proposals ${ }^{128}$ for use of federally appointed registrars to administer the state-prescribed tests, an approach clearly supported by Congress's article I, section 4 power. ${ }^{129}$ There would be no need to incur the expense of providing federal registrars throughout the twenty-one states in which literacy tests are used since Congress could designate the Department of Justice, the Civil Rights Commission, or some other agency to decide in which states, or even localities, the registrars should be used because of suspicion that discriminatory practices might otherwise occur.

Another approach worthy of serious consideration was worked out by Senator Dodd of Connecticut after the demise of the administration effort and offered in bill form by him and twenty-one co-sponsors on July $27,1962 .{ }^{130}$ The central feature of Senator Dodd's bill is the requirement: ( $I$ ) either that the literacy tests be administered in writing or that verbatim transcription of the questions and answers be made, and (2) that a copy of the resulting certified record be filed with the United States attorney for the district and also furnished, upon request, to each individual taking the test (the individual having been furnished, at the time of taking the test, with a printed statement informing him of his rights). ${ }^{131}$ Although a system of federal registrars has the advantage over the Dodd proposal of completely eliminating the time-consuming element of review of the decisions of state registrars, the Dodd plan would assure availability of evidence to make that review much less difficult and at the same time eliminate the need for individual complainants to take the initiative in securing that review, perhaps at the risk of serious economic or other reprisals. Moreover, the Dodd proposal, although limited to federal elections, could clearly be extended, under the enforcement power of the fourteenth and fifteenth amendments, to state elections as well, whereas the use of federal registrars for state elections would raise more serious constitutional questions.

Detailed consideration of proposals such as these is what is called for. ${ }^{132}$ The

that the bill would disfranchise all voters without a sixth-grade education); I08 CoNG. Rec. 7343-44 (daily ed. May 8, I962) (Senator Cooper of Kentucky, fearing that sixth grade would develop into the test of qualification for all).

${ }^{128}$ See U.S. Commission on CIvIL RIGHT, REPORT 139-42 (1959); Heyman, supra note I4, at 21 I13; Horsky, The Supreme Court, Congress, and the Right to Vote, 20 OHIo ST. L.J. 549, 554-56 (I959).

${ }^{120}$ See Ex parte Siebold, 100 U.S. 371 (1880); In re Supervisors of Election, 23 Fed. Cas. 430 (No. 13628) (C.C.S.D. Ohio 1878 ).

${ }^{130}$ S. $3576,87_{\text {th }}$ Cong., $2 \mathrm{~d}$ Sess. (1962).

${ }^{131}$ The bill also specifically prohibits denial of any individual's right to vote in a federal election "on account of any grammatical or clerical error made by such individual on any application" if the individual in fact qualifies and the application so indicates. Cf. note 5 supra.

1s2 The need for sustained effort and study is not fulfilled by merely surveying opinions of numerous professors of constitutional law. The answers received by the subcommittee reflected wide disparity of views, see Hearings 574-664, and many of the opinions seemed to be expressed after only rather sur- 
Senate's failure to do this kind of job during the Eighty-seventh Congress undoubtedly reflects the weakness of its leadership in this field since the death in September 1960 of Senator Thomas Hennings of Missouri, the first chairman of the Subcommittee on Constitutional Rights. Neither the majority leader nor the majority whip is a lawyer; many of the more capable lawyers in the Senate (such as Morse of Oregon and Javits of New York) seem to be regarded by their colleagues as so partisan on civil rights issues that their arguments on the literacy legislation have not received the consideration they merit; the Attorney General is a relatively young man more respected for political talents than for legal scholarship; and the chairmen of both the Judiciary Committee and its Subcommittee on Constitutional Rights apparently still subscribe to a constitutional philosophy whose last vestiges left the Supreme Court with the retirement of James Clark McReynolds (or at least with the resignation of his successor for one year, James $F$. Byrnes).

Federalism, it must be remembered, is a two-way street; and Congress's responsibilities in the federal system are not fulfilled merely by its refraining from undue encroachment on areas primarily of state concern. The many important roll-call votes decided by narrow margins during the Eighty-seventh Congress are a close-athand reminder that everyone in the country has a strong stake in assuring the truly representative character of Congress and the Presidency. But the national interest in protection of voting rights, both federal and state, and indeed of all civil rights, goes deeper than this, to the very heart of what our government and its Constitution stand for. Both the Supreme Court, in Baker v. Carr, ${ }^{133}$ and Congress, in the Civil Rights Acts of 1957 and $1960,{ }^{134}$ have given new recognition to this federal responsibility in the voting field and have made a beginning toward complete realization of the national ideals of representative government. The federal constitution is fully adequate to the task, but the contribution of Congress so far has been less than adequate.

prisingly casual investigation and reflection, considering that they were from a group who frequently counsel the Supreme Court against expressing opinions on constitutional questions without the benefit of full adversary briefs and argument and the impetus of a concrete factual situation unavoidably requiring resolution of the question. In one letter, Hearings 6r4, Professor C. J. Antieau declined to offer an advisory opinion for want of sufficient time to make a full investigation. He expressed the cogent view that even if the tabulated result of an inquiry made in this way were a vote of 150 professors to 3 , the 3 might well be right.

${ }_{133} 369$ U.S. I 86 ( 1962$)$.

134 7I Stat. 634 (I957); 74 Stat. 86 (I960). 